PRIMER NOTE

\title{
Microsatellites from the burbot (Lota lota), a freshwater gadoid fish (Teleostei)
}

\author{
MATTHIAS SANETRA and AXEL MEYER \\ Lehrstuhl für Zoologie und Evolutionsbiologie, Fachbereich Biologie, Universität Konstanz, 78457 Konstanz, Germany
}

\begin{abstract}
We developed 21 polymorphic dinucleotide microsatellite loci, $(\mathrm{CA})_{n}$ and $(\mathrm{CT})_{n^{\prime}}$ for the Holarctic freshwater fish, Lota lota, using an enriched genomic library protocol. The species has an interesting life history because winter-spawning adults migrate over long distances to form spawning aggregations, a behaviour which should maintain genetic homogeneity across large spatial scales. Availability of the reported microsatellites will facilitate the investigation of population genetic structure with regard to postglacial colonization history and conservation strategies. The primers were screened on 30 individuals from a natural population (Lake Constance, southern Germany), revealing three to 24 alleles per locus with expected heterozygosities ranging from 0.48 to 0.93 .
\end{abstract}

Keywords: burbot, Lake Constance, Lota lota, microsatellites, population genetics

Received 17 December 2004; revision accepted 26 January 2005

The burbot, Lota lota (L. 1758), is the only cod (gadoid fish) species that lives permanently in freshwater. Its distribution is Holarctic, and includes nearly all suitable freshwater basins of northern North America, Europe, and Asia (Lelek 1987). However, stocks of the burbot have seriously declined in number and distribution during the last century (Maitland \& Lyle 1991), as they require clean water with high oxygen levels. The burbot shows, for gadoid fish, a unique life history trait, spawning in midwinter under the ice in lakes and sometimes in rivers. In Lake Constance, southern Germany, burbots spawn in the deep parts of the lake in March (Hofmann \& Fischer 2000). The actual spawning event is reported to occur at night, whereby 10-12 individuals merge to form an intertwined ball approximately 2 feet in diameter (Maitland \& Lyle 1991). It is further known that there is migration over long distances to common spawning areas, which makes it likely that burbot populations within certain geographical regions are panmictic. After spawning, the small pelagic larvae engage in long-range dispersal while growing rapidly.

Geographic barriers are often effectively preventing gene flow in terrestrial habitats, which subsequently leads to genetic differentiation of many animal populations. In large water bodies, however, it is less obvious which factors can

Correspondence: Axel Meyer, Fax: +49 753188 3018; E-mail: axel.meyer@uni-konstanz.de promote population subdivision. In the European eel, for instance, recent genetic analyses did not support the longstanding hypothesis of large scale panmixia (Wirth \& Bernatchez 2001). Testing hypothesis derived from life history information with genetic methods is thus important to broaden our knowledge on the dynamics of natural populations. Also, detailed information on the population genetic structure of burbots is crucial for the effectiveness of conservation management programs. To address these and related issues, it requires genetic surveys with a large number of neutral, highly variable genetic markers that provide sufficient resolution for detecting population genetic differences (Koskinen et al. 2004). We developed 21 microsatellite loci to examine patterns of genetic structure within and among burbot populations in the Lake Constance area. This geographical region is particularly interesting because local differentiation of mtDNA suggests the postglacial colonization of the lake from two different refugia (Van Houdt et al. 2003; Barluenga \& Meyer, unpublished).

A partial genomic library enriched for microsatellites was constructed using the methods described by Tenzer et al. (1999) and later modified by Garner et al. (2000). Genomic DNA from one individual was extracted using standard phenol-chloroform methods (Sambrook et al. 1989), and $30 \mu \mathrm{g}$ was digested with the restriction enzyme MboI. Fragments ranging from 400 to 900 base pairs electrophoresed in a $1 \%$ agarose gel and visualized with ethidium bromide 
were excised, cleaned using Qiaquick Gel Extraction Kit (Qiagen), and ligated to specific linkers (Er1Bh1GATCSticky: 5'GATCGGCAGGATCCACTGAATTCGC3' and Er1Bh1Blunt: 5'GCGAATTCAGTGGATCCTGCC3') with $\mathrm{T}_{4}$ DNA ligase at $16{ }^{\circ} \mathrm{C}$ overnight. Pre-hybridization polymerase chain reaction (PCR) amplification was performed for 15 cycles using one of the linker oligos. For enrichment, linked fragments were denatured and hybridized to $3^{\prime}$ biotinylated $(\mathrm{CA})_{15}$ and $(\mathrm{CT})_{15}$ probes in $10 \times \mathrm{SSC} / 0.2 \%$ SDS for 3 hours at $55^{\circ} \mathrm{C}$. The DNA hybridized to the probe was separated using streptavidin magnetic beads (DynaBeads M-280 Streptavidin) by several washes (twice in $2 \times$ SSC $/ 0.2 \%$ SDS at room temperature, twice in $2 \times \mathrm{SSC} / 0.1 \%$ SDS at $55^{\circ} \mathrm{C}$, and once in $1 \mathrm{M} \mathrm{TE} / 50 \mathrm{~mm} \mathrm{NaCl}$ at room temperature). Microsatellite-enriched DNA was then PCR amplified for 20 cycles, cloned into the Invitrogen pCR®II TOPO vector and transformed into chemically competent Escherichia coli cells supplied with the TOPO TA Cloning kit, according to

Table 1 Microsatellites for Lota lota based on a sample of 30 individuals from Lake Constance near University

\begin{tabular}{|c|c|c|c|c|c|c|c|c|c|}
\hline Locus & Primer sequence $\left(5^{\prime}-3^{\prime}\right)$ & Core motif & Size (bp) & $T_{\mathrm{a}}\left({ }^{\circ} \mathrm{C}\right)$ & $n_{\mathrm{A}}$ & $H_{\mathrm{O}}$ & $H_{\mathrm{E}}$ & $F_{\mathrm{IS}}$ & $P$ \\
\hline Llo1 & $\begin{array}{l}\text { F: CCTAACTCGCTGTGTCACTTTC } \\
\text { R: GCACTGTTTAATGCCACTGC }\end{array}$ & $(\mathrm{TG})_{25}$ & $170-200$ & 55 & 12 & 0.93 & 0.84 & -0.12 & 0.10 \\
\hline Llo5 & $\begin{array}{l}\text { F: TACACAGGATGGGGATGTCG } \\
\text { R: TCACCCTAGTATGTCCCTTTACG }\end{array}$ & $(\mathrm{AC})_{7}(\mathrm{AG})_{48}$ & $160-246$ & 55 & 6 & 0.14 & 0.66 & 0.78 & 0.00 \\
\hline Llo6 & $\begin{array}{l}\text { F: GAACCAAAGGCGTTTGTGAG } \\
\text { R: CCTCCAGACAAACCCTCATC }\end{array}$ & $(\mathrm{GA})_{19}$ & $144-154$ & 55 & 6 & 0.50 & 0.48 & -0.05 & 0.28 \\
\hline Llo7 & $\begin{array}{l}\text { F: GATGCGACCATTTGTCTGTG } \\
\text { R: TTTTATTTCACGGGCCTGAC }\end{array}$ & $(\mathrm{GA})_{15}$ & $253-345$ & 55 & 10 & 0.70 & 0.77 & 0.09 & 0.18 \\
\hline Llo8 & $\begin{array}{l}\text { F: AGGCGCCAATATGTAAATGG } \\
\text { R: GACGCTACAGACACGGGTTC }\end{array}$ & $(\mathrm{TC})_{32}$ & $205-286$ & 55 & 24 & 0.90 & 0.93 & 0.03 & 0.68 \\
\hline Llo11 & $\begin{array}{l}\text { F: TGCTGGCTACAGTGGAGGAG } \\
\text { R: CGAGCGTTAAAGAGCTGAAG }\end{array}$ & $(\mathrm{AC})_{17}$ & $136-142$ & 55 & 5 & 0.77 & 0.56 & -0.37 & 0.16 \\
\hline Llo12 & $\begin{array}{l}\text { F: CAAACTGCTCTGCTGTCTGC } \\
\text { R: TCTGTCGAGACTTGGGAAGG }\end{array}$ & $(\mathrm{CA})_{22}$ & $150-168$ & 55 & 7 & 0.57 & 0.65 & 0.13 & 0.10 \\
\hline Llo13 & $\begin{array}{l}\text { F: TGGCTTAATCTCTGGTTGCAG } \\
\text { R: GAGTTCACTGCCATAATCAGTCC }\end{array}$ & $(\mathrm{CT})_{17}$ & $195-220$ & 55 & 6 & 0.50 & 0.60 & 0.17 & 0.38 \\
\hline Llo14 & $\begin{array}{l}\text { F: TATCATGTTGTTATCAGTGCAGAG } \\
\text { R: GGGATGGGAGGATTGAGTG }\end{array}$ & $(\mathrm{GT})_{10}$ & $222-281$ & 55 & 3 & 0.62 & 0.67 & 0.08 & 0.46 \\
\hline Llo15 & $\begin{array}{l}\text { F: ACTCAGGGCTGTGTGGTCTG } \\
\text { R: ACGTGTGCTCCCTTGCTC }\end{array}$ & $(\mathrm{GT})_{13}$ & $169-177$ & 55 & 4 & 0.56 & 0.50 & 0.12 & 0.68 \\
\hline Llo16 & $\begin{array}{l}\text { F: GTGCACGCTCTTTCAATCAC } \\
\text { R: AAAACCCCTGTCTGTTGCAG }\end{array}$ & $(\mathrm{TG})_{17}$ & $246-284$ & 55 & 10 & 0.79 & 0.75 & -0.06 & 0.49 \\
\hline Llo21 & $\begin{array}{l}\text { F: GACACATGCGCTGCACATAC } \\
\text { R: GCCTCAAAAACACAACAGGAG }\end{array}$ & $(\mathrm{GT})_{14}$ & 165-181 & 55 & 7 & 0.83 & 0.71 & -0.18 & 0.64 \\
\hline Llo22 & $\begin{array}{l}\text { F: TGGATGGTTTGAGAGAGACTG } \\
\text { R: GGAGGAGCTGAGCAGTAAGA }\end{array}$ & $(\mathrm{AC})_{17}$ & $250-262$ & 55 & 6 & 0.57 & 0.58 & 0.03 & 0.09 \\
\hline Llo23 & $\begin{array}{l}\text { F: GACAGGTGACAAGACCGATG } \\
\text { R: ACTATGCAGCACCGCACTC }\end{array}$ & $(\mathrm{CA})_{33}$ & $332-364$ & 50 & 13 & 0.66 & 0.79 & 0.18 & 0.12 \\
\hline Llo26 & $\begin{array}{l}\text { F: CACTTTTAGGACCAATACATACACG } \\
\text { R: GGTTCACAGGCTTACATAAATGG }\end{array}$ & $(\mathrm{TG})_{20}$ & 137-151 & 55 & 7 & 0.70 & 0.72 & 0.03 & 0.50 \\
\hline Llo29 & $\begin{array}{l}\text { F: TTCTTTCTCTTCCCTCTGTG } \\
\text { R: CATATATGCAGCGCCTTTC }\end{array}$ & $(\mathrm{AG})_{46}$ & $243-290$ & 55 & 9 & 0.50 & 0.75 & 0.33 & 0.0015 \\
\hline Llo31 & $\begin{array}{l}\text { F: CTGTCCATGTTGCTGTATTC } \\
\text { R: AGCAGAGCACACCTACAGTC }\end{array}$ & $(\mathrm{GA})_{13}$ & $174-186$ & 55 & 8 & 0.70 & 0.67 & 0.04 & 0.61 \\
\hline Llo32 & $\begin{array}{l}\text { F: CACTCCCGAAAAATAAACAC } \\
\text { R: GTTTTCACCCTTCTTACGTG }\end{array}$ & $(\mathrm{GA})_{26}$ & $207-243$ & 55 & 13 & 0.93 & 0.85 & -0.11 & 0.43 \\
\hline Llo33 & $\begin{array}{l}\text { F: GAGGCAGAGTCAAGTGTTTC } \\
\text { R: TCTGTCACCACAGTGAGAAG }\end{array}$ & $(\mathrm{TG})_{13}$ & $221-234$ & 55 & 4 & 0.50 & 0.48 & -0.04 & 0.53 \\
\hline Llo34 & $\begin{array}{l}\text { F: AAGAAGATTGCACAGAGAGC } \\
\text { R: TGACAGTGTTTCCAGACAAG }\end{array}$ & $(\mathrm{GA})_{30} \mathrm{~T}(\mathrm{GA})_{37}$ & $260-294$ & 55 & 17 & 0.77 & 0.88 & 0.13 & 0.17 \\
\hline Llo48 & $\begin{array}{l}\text { F: CACCGTTAGCCTCACAGACC } \\
\text { R: GTGACCATTCCCCTTGTTTG }\end{array}$ & $(\mathrm{GT})_{33}$ & $224-257$ & 55 & 13 & 0.80 & 0.82 & 0.02 & 0.83 \\
\hline
\end{tabular}

$T_{\mathrm{a}}=$ annealing temperature; $n_{\mathrm{A}}=$ number of alleles; $H_{\mathrm{O}}=$ observed heterozygosity; $H_{\mathrm{E}}=$ expected heterozygosity; $F_{\mathrm{IS}}=$ fixation index; $P=$ probability of observing an $F_{\mathrm{IS}}$ as or more extreme as the actual outcome when there is no deviation from Hardy-Weinberg frequencies. Clone sequences used for primer development have GenBank accession numbers AY859759-AY859779. 
the manufacturer's recommendation. Cells were grown on ampicillin-treated agar plates from which individual colonies were picked and regrown for 6-8 h in 96-well culture plates containing $150 \mu \mathrm{L}$ of liquid $1 \times \mathrm{LB} /$ Amp solution with $20 \%$ glycerol. To determine the insert size of clones, M13 forward (-20) and reverse primers were used directly on the bacterial cultures following the PCR protocol of Invitrogen. PCR products were sequenced using the BIGDYE version 2.0 cycle sequencing kit (Perkin Elmer) and fragments were visualized on a Perkin Elmer ABI3100 automated sequencer.

Of 96 clones that were sequenced, 52 contained simple or compound microsatellite repeat motifs with 10 or more repeats, and those that had sufficient flanking regions were selected for primer development using the PRIMER 3 software (Rozen \& Skaletsky 1998). PCR was performed in $10 \mu \mathrm{L}$ reaction volumes containing $5.5 \mu \mathrm{L}$ double-distilled $\mathrm{H}_{2} \mathrm{O}, 1 \mu \mathrm{L} 10$ buffer (100 mm Tris- $\mathrm{HCl}, 500 \mathrm{~mm} \mathrm{KCl}, 15 \mathrm{~mm}$ $\left.\mathrm{MgCl}_{2}\right), 2.0 \mu \mathrm{L}$ primer mix $(0.2 \mu \mathrm{M}$ each forward and reverse primer), $0.8 \mu \mathrm{L} d N T P \operatorname{mix}(200 \mu \mathrm{M}$ each dNTP), 0.2 U Sigma RedTaq DNA polymerase, and about 5 ng DNA. PCRs were run on a Perkin Elmer GeneAmp PCR 9700. An initial denaturation step $\left(94^{\circ} \mathrm{C}, 2 \mathrm{~min}\right.$ ) was followed by 35 cycles of $10 \mathrm{~s}$ at $94^{\circ} \mathrm{C}, 10 \mathrm{~s}$ at the locus specific annealing temperature (Table 1), $30 \mathrm{~s}$ at $72{ }^{\circ} \mathrm{C}$, and a final extension step for $60 \mathrm{~min}$ at $72^{\circ} \mathrm{C}$. Primers consistently producing strong single bands were labelled with the fluorescent dyes FAM-6, HEX, and NED to allow multiplexing. Fluorescently labelled PCR products were visualized on a Perkin Elmer ABI 3100 genetic analyser. Allele sizes were scored against an internal GeneScan-500 (Rox) size standard. Genotypes were obtained using GENESCAN analysis version 3.7 and GENOTYPER version 3.7 software from Perkin Elmer.

For the variation screen, 30 burbots were collected in Lake Constance from a single locality with stony-gravel substrate of the littoral zone $(0-100 \mathrm{~cm}$ water depth) near the village of Egg, approximately $0.5 \mathrm{~km}$ north of the University $\left(47^{\circ} 41^{\prime} 49^{\prime \prime} \mathrm{N}, 09^{\circ} 11^{\prime} 33^{\prime \prime} \mathrm{E}\right)$. Of the initial set of 31 loci analysed, two had fewer than three alleles, eight were difficult to score or did not give reproducible results, and a total of 21 had a reasonable degree of polymorphism (Table 1). Levels of variability detected at these loci was moderate to high, with the number of alleles ranging from 3 to 24 , and expected heterozygosities ranged from 0.48 to 0.93 . All but two loci conformed to Hardy-Weinberg expectations (Table 1) based on exact tests using GENEPOP (web version 3.1; Raymond \& Rousset 1995). While at locus Llo5, the difference between $H_{\mathrm{O}}$ and $H_{\mathrm{E}}$ was highly significant, indicating the occurrence of null alleles at this locus, the $P$ value at locus Llo29 was only slightly below the
Bonferroni corrected significance level of 0.002 (Table 1). Therefore, deviation from Hardy-Weinberg frequencies was more likely the result of small sample sizes at the latter locus (nonamplifying null homozygotes were also not detected). No locus pair showed significant linkage disequilibrium after applying Bonferroni corrections for multiple tests $(P=0.01-1.0)$. The markers reported here will prove useful for monitoring population genetic structure of this rapidly declining commercial freshwater fish.

\section{Acknowledgements}

This work was supported by grants of the Deutsche Forschungsgemeinschaft and the University of Konstanz to AM. We acknowledge Carmen Fehr and Markus Pehr for technical assistance, and Marta Barluenga for helpful discussions.

\section{References}

Garner TWJ, Gautschi B, Röthlisberger S, Reyer H-U (2000) A set of CA repeat microsatellite markers derived from the pool frog, Rana lessonae. Molecular Ecology, 9, 2173-2175.

Hofmann N, Fischer P (2000) Seasonal changes and age structure of burbot Lota lota (L.) and stone loach Barbatula barbatula (L.) in the littoral zone of a large pre-alpine lake. Ecology of Freshwater Fish, 9, 1-5.

Koskinen MT, Hirvonen H, Landry P-A, Primmer CR (2004) The benefits of increasing the number of microsatellite loci utilized in genetic population studies: an empirical perspective. Hereditas, 141, 61-67.

Lelek A (1987) The Freshwater Fishes of Europe, Vol. 9. Threatened Fishes of Europe. Aula-Verlag, Wiesbaden.

Maitland PS, Lyle AA (1991) Conservation of freshwater fish in the British Isles: the current status and biology of threatened species. Aquatic Conservation: Marine and Freshwater Ecosystems, 1, 25-54.

Raymond M, Rousset F (1995) GENEPOP (version 1.2): population genetics software for exact tests and ecumenicism. Journal of Heredity, 86, 248-249.

Rozen S, Skaletsky HJ (1998) Primer 3. Available at <http://wwwgenome.wi.mit.edu/genome_software/other/primer3.html> [accessed on 17 December 2004].

Sambrook J, Fritsch EF, Maniatis T (1989) Molecular Cloning: a Laboratory Manual, 3rd edn. Cold spring, Harbor Laboratory Press, Cold Spring Harbor, NY.

Tenzer I, Ivanissevich SD, Morgante M, Gessler C (1999) Identification of microsatellite markers and their application to population genetics of Venturia inaequalis. Phytopathology, 89, 748-753.

Van Houdt JK, Hellemans B, Volckaert FAM (2003) Phylogenetic relationships among Palearctic and Nearctic burbot (Lota lota): Pleistocene extinctions and recolonization. Molecular Phylogenetics and Evolution, 29, 599-612.

Wirth T, Bernatchez L (2001) Genetic evidence against panmixia in the European eel. Nature, 409, 1037-1040. 